\title{
COMPETITION AND MARKETING BARRIERS UNDER NATIONAL DEFENSE
}

\author{
Nathanael $H$. Engle*
}

\section{UNDERLYING AssUmptions}

\section{Marketing Defined}

Implicit in the title given to the present discussion are the assumptions that marketing barriers exist and that national defense is somehow concerned with, affected by, or affects existing marketing barriers. Marketing is a term not yet widely enough employed in scientific thinking to mean the same thing to all men. For the purposes of this discussion, the authority of the Committee on Definitions of the American Marketing Association is accepted. "Marketing includes those business activities involved in the flow of goods and services from production to consumption." Our question may be stated thus, what barriers or obstacles lie in the path of those who would undertake the business activities involved in the flow of goods and services from production to consumption and how has national defense complicated or been complicated by the existence of such barriers?

\section{National Defense}

Before essaying an answer to this pressingly important question it is necessary in the interests of clarity and brevity to explain what is meant by national defense. National defense is first of all an economic job-the job of producing a two-ocean navy, a modern mechanized army, an invincible air force. In addition, national defense consists in producing all aid short of war for Britain and her allies. In brief, national defense means, in the words of our President, making America "the great arsenal of democracy."

National defense is no less a political job-the job of marshaling the forces of a great democracy behind the economic task in order to succeed in that task. It is a job of organization and administration, a job of cutting red tape, a job of streamlining, oiling, and operating at full speed the machinery of government itself.

National defense is equally a psychological and a social job-the job of building

- A.B., 1925, A.M., 1926, University of Washington; Ph.D., r929, University of Michigan. Adviser on Distribution for the Consumer Division of the National Defense Advisory Commission. Formerly Assistant Director of the Bureau of Foreign and Domestic Commerce, in charge of research and statistics. Former president of the American Marketing Association and former editor of the JourNal of MARKETING, he has written widely on marketing problems. The views expressed in this article are his own, and in no wise to bo interpreted as official expressions of the attitude of the National Defense Advisory Commission.

1 (1935) × NAT. MARKETING REv. I56. 
in the thoughts of the people a will to defend themselves. It is a task of galvanizing the millions of our people into unified action directed at the sole objective of safeguarding democracy.

Thus national defense is total defense-no less. It is the supreme effort and sacrifice of a nation aroused belatedly to the dangers which lie ahead in a world of unscrupulous gangster nations drunk with the blood of conquest and the lust for world dominion. As long as such a world exists, America must maintain invincible armaments. But invincible armaments are impossible without an invincible economy. Hence total defense must contemplate, indeed must build upon, a strong and effective economic structure. It is here that national defense overrides marketing barriers, for national defense can brook no obstacles to economic efficiency, and most marketing barriers must be considered as obstacles in the way of economic efficiency. The chief concern and hence the meaning of national defense for this article must therefore be economic efficiency. ${ }^{2}$

\section{Economic Barriers to Marketing Under Total Defense}

Two sets of obstructions to the free market may be observed-one set economic, the other legal. Economic obstacles inhere in the pattern of distribution channels which has emerged from the competitive struggle for market control, in the costs of distribution, and in the system of prices and price policies which prevail. ${ }^{8}$

How can one say that distribution channels, distribution costs, and prices and price policies are marketing barriers? They are not barriers in the fundamental economic sense, but rather comprise the mechanism whereby economic resources are allocated to socially desirable ends. In this sense, channels of distribution and particularly costs and prices determine, within limits, where and how the scarce factors of production, land, labor, capital, and enterprise, shall be utilized in satisfying the wants of society. In the long run only those enterprises can continue which meet the tests imposed by the cost-price relationship,

To the individual who would enter the field of marketing, however, the existing market structure and the conditions of resource use which prevail within it are very real barriers or obstacles to free action which must be faced or overcome as the price of success. The existing pattern of distribution, for example, while it provides opportunities within fairly wide limits for new and improved methods and devices, is nevertheless circumscribed at a number of points. Thus the growth of direct selling by producers quickly encounters obstacles, not the least of which is the greater efficiency of utilizing wholesalers' services for most commodities. Again, the expansion of chain store selling by the well-known cash-and-carry method has its limits in deeply rooted consumer buying habits, and cannot expand beyond that part of the market which is able and willing to pay cash and carry its own purchases home.

${ }^{2}$ For a recent discussion of the meaning of economic efficiency, see Engle, Measturement of Economic and Marketing Efficiency (194I) 5 J. MARKetino 335.

${ }^{3}$ See Craig and Gabler, The Competitive Struggle for, Market Control (May 1940) 209 Annals 84; also Engle, The Straggle for Market Control (I94I) T. N. E. C. MonOGRApH No. 17, at 159. 
The rôle of distribution costs as a barrier to marketing will be discussed more fully later. The fact that it requires labor, capital, and skilled management, all of which must be paid for, to conduct a marketing enterprise, is an easily understandable obstruction to successful and efficient distribution. The business junk yard is filled with the wrecks of those who failed to count the cost of distribution before embarking upon ill-fated marketing ventures. Similarly, prices and pricing policies are restrictive of free action in the market place. Too little known are the intricate processes by which prices are set on the multitude of commodities which flow through our markets. To the unskilled in pricing or to those unfamiliar with the pitfalls of price setting, the price system is a barrier to marketing activity. Indeed, it accomplishes its more vital function of resource allocation by very reason of the fact that it quickly becomes a barrier to the success of the incompetent.

\section{Distribution Channels}

With these thoughts in mind attention is first directed to the possible effects of a total defense program upon certain of the economic barriers to marketing. First of all, it seems reasonable to expect substantial changes in the existing distribution channels to result from defense. Starting with the manufacturers, defense spending is rapidly filling order books to capacity; directly through government orders, and indirectly through increased business from civilian buyers who find steadier work, more work, better pay. Responding to pressure for speedy production of government contracts and early deliveries, and finding that the long-standing buyers' market has become overnight a sellers' market, manufacturers, it seems reasonable to anticipate, will be less and less concerned with those expensive and elaborate schemes for direct selling which have engaged their attention in the recent past. More efficient sales outlets will be in demand. Agents, brokers, wholesalers, all specialists in performing the functions of the wholesale market, should look for additional business as a consequence of the reduced emphasis on direct selling. ${ }^{4}$

Some may say, at this point, what of the chains, what of the mass distributors, are they not more efficient than the wholesale agencies mentioned? The answer is at once yes and no; yes, in the sense that mass distributors have been able to cut costs on the goods they sell by the methods they employ; no, in the sense that, since they do not normally carry a full line of merchandise nor do they perform the normal range of marketing functions, their costs are not comparable to those of other distributors. On a strictly comparable basis as to functions performed, chains are not always more efficient than independents.

The stream of distribution may be likened to the delta of a great river. The main channel is wide and deep and can easily accommodate the largest boats. It may be more devious than some of the sloughs or branches which have cut their way directly to the sea but which are apt to be narrow and shallow. These can carry some of the lighter draft vessels directly and more quickly to their destination but all the traffic cannot or may not care to utilize these routes.

'See Engle, Adjustment of Wholesaling to I94I and After (I94I) 5 J. MARkETING 43I. 
Independent wholesalers and retailers carry the main stream of goods which flow from producers to consumers. In 1935, independent retailers handled about twothirds of all retail business covered by the Census; chain stores accounted for nearly 23 percent; department stores had nearly ro percent; very small amounts were handled by mail-order selling and by house-to-house selling by manufacturers and others. Supermarkets were not shown separately but classified with either chains or independents.

Just as the delta of a river yields to the vagaries of the river's flow, cutting new channels here, returning to old ones, with nothing constant but change, so it is with the channels of distribution. Competitive forces, which stem from consumer buying habits, trade practices, and the urge for profits, condition fluctuations in these channels. Each channel has its own limiting factors. Independent retailers find their chief market in the patronage habits of the upper and lower income groups with some support from middle income families where, for various reasons, shopping for cash and carrying the goods home is not always convenient. The rich, by and large, patronize the better-grade independents by choice. The poor, by and large, support the small retailer by necessity. Giving part of their business to cash-and-carry outlets when they have the cash, the bulk of the purchases of those with very small incomes goes to the dealer who lends them credit from one pay day to the next and who tides them over periods of unemployment and adversity.

It is the middle class, by and large again, which have the cash, the time, and the inclination to buy from the cash-and-carry chains, the supermarkets, and other mass outlets. None of these groups is hard and fixed, but they nevertheless constitute limits to the expansion of the various types of distributors, even though the limits are flexible from time to time and from place to place.

Persistent evidence in the statistics that chains have about reached the limits of the demand for their brand of service leads one to conclude that no very great expansion lies ahead for them in the nation as a whole. ${ }^{5}$ Competition, moreover, in the form of supermarkets and chain-trained and other up-and-coming independents, ${ }^{6}$ some of whom band together to secure buying advantages or use the cash-and-carry technique of selling, still further circumscribes chain expansion on the supply side. Defense prosperity may witness a continuation of this trend. In so far as the upper income group participates in recovery, larger patronage of the independents should follow. With fuller employment and steadier work there may be some falling away of the lower income groups to the mass distributors. Offsetting

\footnotetext{
F For an excellent analysis of the chain stores, see Beckman and Nolen, The Chain Store Pronlem (1938).

'It should be noted, parenthetically, that direct buying is not new with mass distributors but is a practice engaged in by many independent retailers. See White, Cooperative Retail, Buying AssociaTroNs (r930) 164 .

The phenomenal expansion of supermarkets in the food field deserves much more than this footnote comment. The absence of official statistics makes it almost impossible to appraise its growth on a comparable basis with other retailing types. Moreover, supermarkets cut across the retailing picture with both independent and chain systems owning and operating them. Sce Super MArket MerchanDIsive (Zimmerman, editor) for articles on the subject.
} 
this trend is the probable shift of more of the middle income brackets to the independents. As unemployment wanes and disappears, more and more families may be found with both husband and wife working. Or wives may work while their husbands are in the armed forces. Such families have little time for shopping and may therefore utilize the services of independent retailers. Even though prices are slightly higher their larger incomes permit the enjoyment of the greater convenience of delivery and credit service. It is reasonable, however, to expect that the cashand-carry chains will hold their own and possibly share in the general expansion of business.

Department stores are in a different class. Large-scale direct buyers, they sell on a service as well as a price basis. Enjoying roughly to percent of all retail business in the nation, there is evidence that they, like the chains, have reached the approximate limits of the market for their type of service. ${ }^{8}$ A period of prosperity, however, may well provide enlarged volume, at least proportional to the general expansion. On the other hand, if competition from other mass distributors and from independent specialty shops develops from defense prosperity, department stores may encounter additional barriers. High operating costs have cursed the department store field

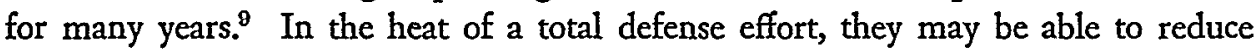
their margins by imposing rigid economies on all of their operations. If, instead, they yield to the temptation of easing up during the good times, they may find in their cost curves a still greater barrier to their expansion.

Cooperatives, another type of direct buying institution, are of two varieties, consumer owned, and distributor owned. The first can be quickly dismissed since it represents but an infinitesimal part of the retail market at this time. Little reason to anticipate much if any change in the consumer cooperative movement as a consequence of defense is apparent. If anything, the distractions of defense activities, the decentralization with consequent population shifts, the expanding incomes may be expected to muddy the waters of cooperative ventures and raise barriers to expansion. Distributive cooperation, on the other hand, should continue its progress. Combining as it does the advantages of large-scale purchasing with those of more personalized selling and service to consumers, the voluntary chain should be in a strong position to take advantage of the defense-generated prosperity. ${ }^{10}$

\section{Distribution Costs}

It is most important under total defense conditions that the barrier aspect of all marketing channels be minimized and the smooth flow of commodities facilitated. The emphasis will have to be on efficiency in marketing throughout all channels. Two areas need to be watched closely, distribution costs and commodity prices.

\footnotetext{
${ }^{B}$ There are of course variations between markets as between chains. Only the national averages are considered here.

${ }^{\circ}$ See Taylor, Progressive Retail Management (May 1940) 209 Ansıls 46, 49; operating cost studies of department stores, Harvard University Graduate School of Business; reports of the Controllers Congress, Nat. Retail Dry Goods Ass'n.

${ }^{10}$ For a basic study of distributive cooperation, see WhITE, op. cit. supra note 6, passim; sec also Blankertz, Markettng Cooperatives (r940).
} 
Spending, as we do, about one-third of the total national income on distribution costs, it is clear that such costs may easily represent a substantial barrier to consumption, as well as a hurdle which must be overcome by new entrants into the field of marketing. ${ }^{11}$ It is imperative in times like these that distribution costs be kept to a minimum consistent with the efficient performance of the marketing functions. Cost accounting for distribution should be in order at each level of the marketing process. It is only through constant vigilance on the part of distributors based upon knowledge of individual items that excessive expansion of marketing costs can be avoided.

\section{Prices and Pricing Policy ${ }^{12}$}

It is at the pricing level that new entrants into the field of marketing usually awake to the fact that there are market forces at work which raise a powerful barrier to free action. Particularly important under national defense is the prevention of excessive price barriers to consumption of individual commodities both for civilian and military uses. Even more vital is the necessity for clipping the wings of inflation before the bird begins to fly. Demand factors, when taken alone, point to an upward trend. Billions of dollars for defense spell not only more direct demand for military goods and services; indirectly, through enlarged employment and purchasing power, they add up to greatly expanded demand for a wide range of consumer goods. In the end it seems inevitable that the demand forces must eventuate in strong business recovery and a sellers' market. Those who look no farther conclude that herein lies a parallel with World War I and that price increases, even inflation, are inevitable.

Fortunately for the American people, supply conditions render such an outlook most misleading. With huge surpluses of many basic agricultural products hanging over the market, and with export outlets almost completely cut off, it is difficult to envisage any very sharp increases in prices of most farm products, to say nothing of inflation. Again, in the manufacturing field, there remains, with some exceptions, much unused plant capacity, and a large army of unemployed labor. New capacity can be readily constructed where needed as long as labor and materials are available. Shortages may develop because of limited supplies of specially skilled labor, or because of inability to import commodities not available at home. Thus prices of an unknown but probably small number of items may rise. But as long as it is possible to marshal productive capacity to match increased demands no general widespread spiraling of prices should follow. On the contrary, in areas where plants have been inactive or operating at but a fraction of capacity, increased output may be had at a reduced unit cost, thus offsetting price increases in other less fortunately situated industries. The fact that production has been expanding rapidly

\footnotetext{
${ }^{11}$ See Stewart and Dewhurst, Does Distributton Cost Too Much? (1939); Engle, Costs and Profits in Marketing (May 1940) 209 ANNaIs 122; Engle, Distribution Cost Analysis by Commodities (Ninth Boston Conference on Distribution, Sept. 21, 1937).

${ }^{12}$ See Edwards, Pricing Processes and Policies (May 1940) 209 ANnsls 108; Mason, Nelson and Keim, Price Behavior and Business Policy (1940) T. N. E. C. Monograph No. I; Gilbert, Export Prices (1940) T. N. E. C. MoNOGRAPH No. 6.
} 
under the defense program while the price level has moved upwards but very little attests to the validity of this analysis.

\section{Legislative Barruers to Marketing Under Total Defense}

Among the legal obstacles to free marketing activity are the many fungus growths of federal, state, and local laws which have mushroomed on the statute books of the nation, especially during the damp decade of the thirties. Worst of these clammy parasites, which make slippery footing for those who would tread the path of efficient marketing, are chain store tax laws, fair trade, and unfair practice acts. Each of these in its own way sets up obstacles to specified types of marketing, to marketing practices, or to the free determination of prices. Chiefly state and municipal legislation, some of these laws have been supplemented, aided, or abetted by federal statutes.

\section{National Legislation}

Since comprehensive national defense cannot be achieved short of general economic efficiency, legislative barriers to marketing must be appraised from the defense point of view in exactly the same terms as the economic barriers; they must, that is, be judged by their effect on efficient distribution. Every piece of legislation which touches upon marketing activities directly or indirectly is of concern to national defense to the degree that it blocks or facilitates efficient operations in the free market. A wide range of national.legislation now encumbers the statute booksfar too extensive to permit here of more than brief mention of a few of the recent and significant acts. Equally brief must be our statement of the underlying defense principle upon which appraisal and action may be based.

National laws which touch marketing practices range from the general anti-trust statutes through social legislation, specific agricultural marketing and foreign-trade laws, and the regulation of such marketing functions as transportation, under the Interstate Commerce Commission, and communications, under the Federal Communication Commission. By no means all of these laws are in the barrier class.

Anti-trust legislation, which heads the list in importance, aims at the elimination of obstacles to free competition, at the removal of trade restrictions, at monopoly and monopolistic practices. Total defense objectives are much the same in the long run. The great hue and cry raised in the press over seeming conflict between the enforcement proceedings of the Anti-trust Division of the Justice Department in the petroleum industry and the attitude of the National Defense Advisory Commission was not entirely justified. Long-run objectives coinciding, the question of timing of action which might delay the immediate procurement program is the only issue. Thus, it is possible that action, designed to break up vertical or horizontal combinations allegedly operating in restraint of trade, may prove unwise at a time when all-out efforts for defense are the major desideratum. Especially is this true when no question of efficiency is at issue but only the question of higher than 
justifiable prices. Prices may be brought down, at least for the duration of the emergency, by less drastic measures, leaving until more peaceful days the task of trust-busting. ${ }^{13}$ In the long run, "we, the people" are convinced that competition serves our ends better than monopoly in most economic activity. Where monopoly is inherent in the nature of an industry, it is accepted and regulated. Where monopoly cannot be justified or regulated, the anti-trust laws are designed to eliminate it.

The Robinson-Patman Act, which was designed to equalize the buying advantages of large- and small-scale operators, is a natural outgrowth of the Sherman Act, the Clayton Act, and the Federal Trade Commission Act. While it does set up obstacles to utter freedom of marketing activity, its avowed purpose is to restrict only unfair or monopolistic practices, presumably inimical to the best interests of consumers and marketers alike. National defense efforts introduce no change in this basic philosophy.

Not so with other types of legislation of a more restrictive nature. Laws which inject inflexibilities into the pricing structure obstruct effective marketing and run counter to the national defense effort. Among these are tariff barriers which shut out or limit the flow of essential commodities. The conflict with defense from such measures is well illustrated by the requirement that military purchases of woolen goods be confined to domestic wool. On representation of the Consumer Division of the National Defense Advisory Commission, this limitation was lifted with the result that unnecessary price increases were averted or minimized. ${ }^{14}$ Tariff and other restrictions which create artificial shortages of badly needed commodities that are abundant in world markets are clearly barriers which should not be tolerated by a nation aiming at speedy total defense.

One other federal statute, among the many which affect.marketing in varying degrees, deserves mention here. The Miller-Tydings Act essentially extends the rights of resale price maintenance under state fair trade laws to interstate commerce. Passed as a rider to an appropriations bill, this law encourages price setting with its concomitant rigidities throughout the market structure. Taken in conjunction with some of the state laws next to be discussed, the Miller-Tydings Act is definitely earmarked as one of the barriers to the free market, which runs counter to the interests of a nation arming itself for defense. ${ }^{15}$

While other federal statutes bearing on market distribution, such as were briefly mentioned above, exist, they do not, for the most part, constitute barriers from the standpoint of national defense in the same sense or to the same degree as do those

\footnotetext{
${ }^{23}$ See the discussion of divorcement of production and distribution in Cook, Legislative Restrictions on Marketing Integration; Edwards, Economic Implications of Business Boundary Laws, both supra this issue.

14 Address by Miss Harriet Elliott at the annual meeting of the National Consumers League, New York, N. Y. Consumer Division, Nat. Def. Adv. Comm., release, Jan. $x x, 1941$, at 6.

${ }^{15}$ See testimony of Dr. Corwin Edwards of the U. S. Dept. of Justice before the T. N. E. C., Feb. I0, 194x.
} 
singled out for discussion. ${ }^{16}$ For any specific law the general principle applies that wherever the statute does prove to be a serious handicap to efficient and economical marketing, it may be taken for granted that such legislation runs counter to public interest under a total defense régime.

\section{State Legislation}

More serious in the sense that they are more numerous and, with possible exceptions, free of federal control, are the legal marketing barriers of the various states. Over forty states have whelped wolfish resale price maintenance laws which parade under the sheep's clothing of fair trade.17 Fair to whom, is the question which consumers raise. Since the objective of these laws is to prohibit the free determination of prices by wholesalers and retailers, their end result is to destroy one of the major bases of competition in a free market. The facts adduced by studies of the actual effects on prices under these laws, that prices have not been increased, in fact may have been reduced somewhat on the average, are beside the point. Actually, minimum prices have been raised; consequently those consumers who buy at the minimum are penalized. The main point, however, is that such legislation militates against free competitive price determination at every level of the market, and consequently has the effect of freezing an existing market structure. Obviously here is a barrier or an obstacle to new and improved methods which might cut distribution costs and reduce prices to consumers. Indeed such new methods would have difficulty in establishing themselves as long as they are deprived of the right to present their case to consumers in the understandable language of lower prices. ${ }^{18}$

Closely akin to resale price maintenance legislation are the so-called unfair trade practices acts which have been passed by some thirty states. These laws purport to prevent unfair competition by prohibiting sale of commodities below cost. Taken at face value little or no objection can be made to this principle, certainly not from the national defense angle. Only when cost is interpreted by some artificial and unrealistic formula do these laws become marketing barriers. Where these laws permit each merchant to set prices on the basis of his own costs, competition continues to function. But when costs are defined arbitrarily and raised to excessive levels, without benefit of a scientific cost survey, as appears to have been true in Colorado recently, the legislation becomes restrictive and tends to raise prices. ${ }^{19}$

In addition to fair trade and unfair practice acts, a large number of states have introduced and some have passed tax laws designed to curb the growth of chain store distribution. Quite apart from the legal merits of singling out a particular type of retailing for special persecution, the incidence of chain store taxes tends to

\footnotetext{
${ }^{20}$ See, e.g., legislation covered in Note on Governmental Product Favoritism, supra this issue.

17 See Oppenfeim, Recent Price Control Laws (I939).

${ }^{28}$ For an analysis of fair trade legislation, sce Grether, Price Control Under Fair Trade LegisLAtion (r939); Grether, Marketing Legislation (May 1940) 209 ANnats 165. For a trade survey, see Ostlund and Vickiand, Fair Trade and the Retail. Drug Store (Druggists Research Bureau, 1940).

${ }^{20}$ According to newspaper accounts this situation has been investigated by the U. S. Dept. of Justice.
} 
be upon the prices charged by the chains. ${ }^{20}$ To the extent that chain prices have been lower than those charged by independents, consumers have profited. By the same token, consumers tend to bear the brunt of chain store tax legislation where such laws either compel the chains to raise their prices or to close their doors. At best it amounts to the state raising revenue by tapping the savings of those consumers who patronize the chains. Since chains have established a reputation for efficiency in the performance of those distribution tasks which they undertake, and since special chain taxation tends to offset chain store advantages and raise costs, chain store taxation is definitely in the barrier class.

A fourth group of state laws, those classified as interstate trade barriers, are also of significance to national defense. Adequately covered elsewhere in this symposium, suffice it to point out that many of the acts falling in this category are apt to conflict definitely with national defense efforts. Thus restrictions on certain types of transportation may impede the speedy and efficient movement of materials across state lines. Again, should shortages develop in particular commodities, such as butter, state barriers to the importation and sale of substitutes would run counter to defense. ${ }^{21}$ Such laws should be vigorously combated whenever and wherever they interfere seriously with defense efforts. Even where the federal government has no jurisdiction over state legislative barriers to the free market, it seems inevitable that local public opinion will rally to the support of the government and see to it that obstacles in the way of effective total defense are removed. Any other policy would spell the inconsistency of persisting in courses of action directly contrary to the dominant interest of the nation.

Finally, there is a potential threat to defense efforts in a type of state legislation which has not yet made perceptible headway with legislators. Efforts have been made to secure the passage of laws, clearly in the barrier class, designed to prohibit business men from simultaneously engaging in manufacturing or processing and marketing or distribution activities. ${ }^{22}$ Reminiscent of ancient guild restrictions, these laws aim at the erection of barriers around traditional types of business activity and the prevention of anyone not specializing in a particular occupation from encroaching into other fields. Thus retail drug stores or soda fountains would be prohibited from manufacturing ice cream, retail grocers would not be allowed to handle drug store items, and public utility companies would be prevented from selling appliances. Running counter as they do to the strong current in merchandising practice of handling wider and more generalized lines of commodities by a growing variety of stores, it would seem that there is little likelihood of their success. Organized minority trade groups continue to push for such legislation, in

\footnotetext{
${ }^{20}$ See Due, The Incidence of Chain Store Taxation (1940) 5 J. MarKeting 128.

21 For discussion and criticism of existing barriers to margarine, see Truitt, Interstate Trade Barriers in the United States; Note on Governmental Product Favoritism, both suprd this issuc.

${ }_{22}^{2}$ Federal, state and local enactments and proposals of this type are collected by Cook, Legislative Restrictions on Marketing Integration; McIntire and Rhyne, Municipal Legislative Barriers to a Free Market, both supra this issue. They are analyzed from the general cconomic point of view by Edwards, Economic Implications of Business Boundary Laws, supra this issue.
} 
the ever-springing hope of the business man that he can somehow get his business out of the competitive class. But the chances of success would seem to be slight. Growing self-consciousness of consumers coupled with the self-interest of competitive business groups should be able to stem the tide.

Contributing to hope for a more liberal policy is the fact that many, if not most, of the various types of barrier laws were the fruit of the depression era, now definitely on the wane. They represented the blind groping for an easy solution to problems which were deeply rooted in fundamental economic maladjustments. Moreover, the results of these palliative measures have generally fallen far below the expectations of their sponsors. ${ }^{23}$ The net of these factors is that the elimination or minimization of both federal and state legislative barriers to marketing, in so far as they are also barriers to national defense, should not prove impossible.

\section{Conclusions}

What conclusions can be drawn from this brief examination of economic and legislative barriers to marketing, as they impinge upon national defense efforts? National defense cannot reshape overnight the trend of thought and action which through the years has built marketing barriers. Hence, it is necessary to differentiate the more immediate outlook from that of the longer run.

In the immediate future the conclusion seems warranted that some success may be achieved in reducing economic barriers to efficient marketing. For example, a shift towards more efficient distribution channels is already in evidence. Efforts towards reducing distribution costs are afoot. Limitations on speculative excesses and avoidance of price spiraling are recognized as essential to defense. With the transition from business recovery to widespread prosperity, it may be anticipated that additional gains will be made in minimizing the economic barriers to marketing. The very pressure of a total defense effort will contribute to this end. At the same time constant vigilance must be exerted to avert the tendency for new barriers to appear under the guise of defense-generated necessity.

On the legislative front, the outlook is less clear. It would appear reasonably certain that defense requirements for efficient distribution should override any national legislative barriers. Initial progress has been made, as noted above, in the relaxation of the domestic wool purchase requirements. Other obstacles to total defense will undoubtedly crumble under the impact of the requirements for building a strong bulwark for our democracy. State legislation will probably be slower to yield, so that immediate relief from the multitude of state marketing barriers may not be realized. Ultimately, however, as defense becomes more and more a stark reality throughout the nation, state barriers, too, should give way to the necessity for building that strong and efficient economy without which no national defense effort can succeed.

\footnotetext{
${ }^{33}$ Recent accounts of cancellation of fair trade contracts by manufacturers illustrate this. See, e.g., action of Denton Sleeping Garment Mills in issuing a folder to customers entitled, Farewell Fair Trade, J. Commerce and Commercial, Feb. II, I94I, at Ir.
} 